\begin{tabular}{|c|c|c|}
\hline Beitr. Ent. & Keltern & ISSN 0005-805X \\
\hline $\mathbf{5 5}(2005) 2$ & S. $279-288$ & 27.12 .2005 \\
\hline
\end{tabular}

\title{
On the ecology of bumble bees of the Talysh Region, Azerbaijan
}

\section{(Hymenoptera, Apoidea, Bombus)}

With 1 figure

Halid A. Aliev

\section{Summary}

The Caucasian isthmus, which began to take shape in the tertiary period, is characterised by the presence of various plants and animals both of boreal and tropical origin. These characteristic species are mostly endemic. They are concentrated in the mountain systems of the Greater and Lesser Caucasus and alsoTalysh. The bumble bee fauna of Talysh contains 22 species belonging to two ecological groups : mesophile - Bombus lucorum L., B. zonatus apicalis SKOR., B. daghestanicus RAD., B. eriophorus caucasicus RAD. and xerophile species of the high mountains and steppes, most of which are endemic - B. argillaceus Scop., B. simulatilis Rad., B. armeniacus Rad., B. alboluteus PAl., B. vorticosus Gerst., B. mlokosiewitzii Rad., B. incertus Mor., B. persicus RAD., B. melanurus LeP.

\section{Zusammenfassung}

Der kaukasische Isthmus, der sich im Tertiär herauszubilden begann, ist durch verschiedene Tiere und Pflanzen sowohl borealen wie tropischen Ursprungs charakterisiert. Die meisten dieser typischen Arten sind endemisch. Sie konzentrieren sich in den Gebirgssytemen des Hohen und des Niederen Kaukasus wie auch im Talysh. Die Hummelfauna des Talysh umfasst 22 Arten, die zwei ökologischen Gruppen angehören: den mesophilen Arten - Bombus lucorum L., B. zonatus apicalis Skor., B. daghestanicus Rad., B. eriophorus caucasicus RAD. - bzw. den xerophilen Arten des Hochgebirges und der Steppen, von denen die meisten endemisch sind - B. argillaceus Scop., B. simulatilis Rad., B. armeniacus RAD., B. alboluteus PaL., B. vorticosus Gerst., B. mlokosiewitzii Rad., B. incertus Mor., B. persicus Rad. und B. melanurus Lep.

\section{Key words}

Bombus, species diversity, distribution, ecology, foodplants

\section{Introduction}

The Caucasian isthmus began to form during the tertiary period. The presence of different types of landscape and climate in Talysh result from this geological age and the geographic position of the region (Fig. 1). Talysh has a rich flora and fauna, containing many endemic species. The climate is humid subtropical in lowlands and foothills and dry continental in the area of mountain xerophytes in Diabar Rift Valley (Zuvand), between 1700 and $2500 \mathrm{~m}$ a. s. 1. The lowland and lower colline landscape is formed by 
three parallel ridges, covered by humid forests of hyrcanian type, reaching up to $1000 \mathrm{~m}$. They consist of relicts of the tertiary period such as Parrotia persica, Quercus castaniefolia, Albizzia julibrissin, Zelkowa carpinifolia, Pterocarya pterocarpa, Gleditschia caspica, Acer velutinum, Buxus hyrcaniana, Danae racemosa, Ruscus hyrcanianus, Ilex hyrcaniana, Laurocerasus officinalis. The second landscape dominating above $1500 \mathrm{~m}$ a. s. 1., is a belt of dry steppes with prevalent Astragalus, Akantolimonus, Stachys, Salvia, Thymus, Onobrychis cornuta, Achillea, Euphorbia, Stipa, Eryngium, Scorzonera, Ferula, Prangos, Tanacetum. Small areas of subalpine vegetation also occur.

Information for Talysh about distribution of bumble bees (Bombus spp.) in these different landscapes, their trophic relationships and other aspects of ecology is very scarce (Aliev 1980, 1984, Baker 1996, Skhirtladze 1979), whereas the composition of the fauna of 22 species seems quite clear (Aliev 1978).

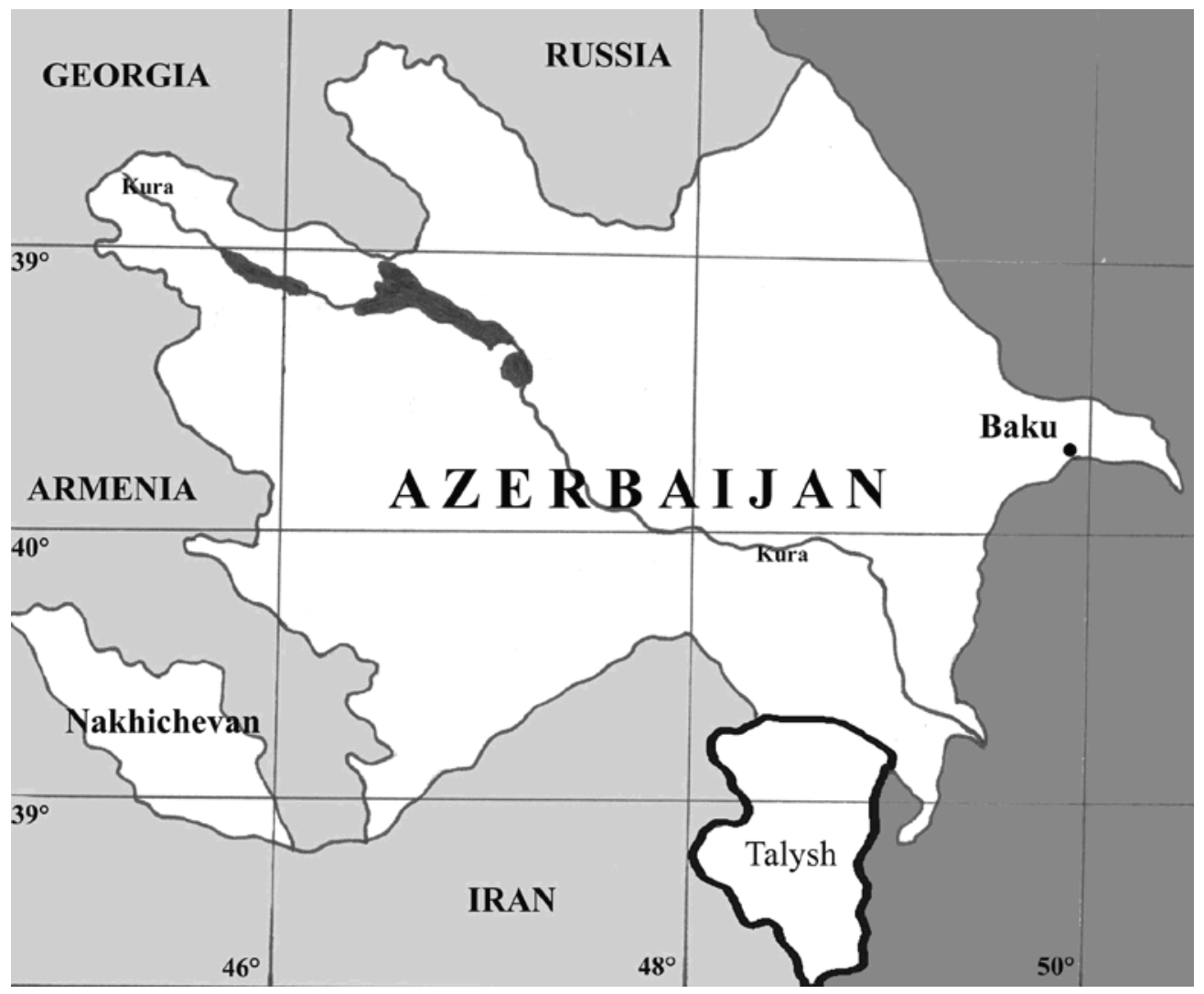

Fig. 1: Position of the study area Talysh in Azerbaijan.

\section{Material and methods}

Material for the present paper was collected by the author, A. Bogachev, R. Effendi, P. Kasarjan and E. Selivanchik since 1929 in different landscapes and biotopes in Talysh. Specimens were collected using traditional methods such as sweep-netting and netting of 
individuals. Trophic relationships were established by the registration of plants on which each bumble bee was recorded feeding and the analysis of pollen of queens and workers. Specimens were determined using the binocular microscope MBS - 1 . The material is deposited in the Institute of Zoology, Azerbaijan Academy of Sciences.

\section{Results}

Data on species composition, distribution, and trophic relationships of bumble bees (Bombus Latreille, 1802) of Talysh are presented below.

\section{Bombus persicus Radoszkowski, 1881}

Material: Azerbaijan, Lerik, Zuvand Kemyrkei Mt. 12.07.1987, 2 ㅇ ㅇ , leg. H. Aliev.

Distribution: Caucasian sub-endemic. Occurs in Greater Caucasus, Transcaucausia, north-eastern Turkey and northern Iran (Skorikov 1938, Aliev 1984, Baker 1996).

Remarks: Inhabits subalpine and alpine meadows (Aliev 1984). In Talysh it is found in the subalpine belt at $2300 \mathrm{~m}$ a. s. 1. Nest underground.

Food plants: Trifolium canescens, Vicia balansae, Veronica kurdica, Betonica grandiflora, Thymus sp., Salvia sp., Lamium album, Cirsium arvense, Echinops sp.

\section{Bombus laesus Morawitz, 1875}

Material: Azerbaijan, Lerik, Galabyn 10.08.1985, 1 ơ , leg. H. Aliev.

Distribution: Occurs in steppe and forest-steppe areas from Moldova and the Crimea to the South Ural. In the Caucasus it is found in Dagestan, eastern Georgia, western Azerbaijan, and Armenia. It also occurs in north-east Turkey, north-west Iran, and in Kazakhstan (foothills of Tien-Shan) (Skorikov 1931).

Remarks: A common species in Transcaucasia found in steppe meadows and steppes both in plains and foothills, as well as in montane steppe plateau. In Talysh it is found in montane steppe meadows. Nest unknown.

Food plants: Prunella sp.

\section{Bombus daghestanicus Radoszkowski, 1877}

Material: Lenkoran distr., glade 11-12.06.1929, $0^{\star}$ and + , leg. E. Selivanchik.

Distribution: Caucasian sub-endemic. Occurs in Daghestan, Transcaucasia and northeasterrn Turkey (Skorikov 1923, Aliev 1984).

Remarks: Occurs in foothill steppes, montane oak-ash forests, and subalpine meadows (Aliev 1984). In Talysh it is found in lowland hyrkan forests. Nest above the ground.

Food plants: Prunella sp., Betonica grandiflora, Senecio orientalis, Carduus thoermeri. 


\section{Bombus mlokosiewitzi Radoszkowski, 1877}

Material: Talysh, Tuli 16.07.1936, ơ, leg. A. Bogachev.

Distribution: Caucasian sub-endemic, mountain species. Distributed in Transcaucasia and northeastern Turkey (Skorikov 1938, Reinig 1974).

Remarks: Occurs at edges of montane decidous forests, in glades of tall grass near the upper edges of the forest, and in subalpine meadows (Aliev 1984). In Talysh it is rare species, found in middle montane forests. Nesting above the ground.

Food plants: Cirsium sp.

\section{Bombus silvarum (Linnaeus, 1761)}

Material: Talysh, Zuvand 14.06.1980, ơ, leg. Effendi.

Distribution: West Palaearctic species occcurring in meadows and steppes. Distributed in South, Central and partly in North Europe, and in Crimea, South Ural, and on islands in the Mediterranean Sea (Skorikov 1938, Panfilov 1957).

Remarks: In Azerbaijan it is found in the Lesser Caucasus in montane meadows and glades in oak-ash forests with admixed hawthorn (Aliev 1984). In Talysh it is found in montane steppes. Nest above the ground.

Food plants: Carduus sp.

\section{Bombus simulatilis Radoszkowski, 1888}

Material: Azerb. SSR, Lerik, Gilidara 27.07.1976, 2 ఛ

Distribution: Caucasian sub-endemic. Reported from Transcaucasia and north-eastern Turkey (Skorikov 1938, Reinig 1974, Aliev 1984).

Remarks: Mainly in mountain steppes and meadows. In Azerbaijan it is found in the Lesser Caucasus in montane steppe meadows and in open oak-ash forests mixed with hawthorn and christs-thorn, as well as in subalpine meadows (Aliev 1984). In Talysh it is found in montane steppes. Nest above the ground.

Food plants: Eryngium nigromontanum, Salvia sp., Teucrium parviflorum, Echinops sp., Carduus thoermeri.

\section{Bombus zonatus apicalis Skorikov, 1935}

Material: Talysh, Zuvand 20.05.1980, 5 ㅇ ㅇ , leg. R. Effendi

Distribution: Nominate subspecies Bombus zonatus zonatus Smith is found in the Balkan Peninsula, southern Moldova and Ukraine, in lower part of Don River, the Caucasus, north-east Turkey and northern Iran (Skorikov 1938). Bombus zonatus apicalis occurs throughout Transcaucasia.

Remarks: In Azerbaijan occurs in the Lesser Caucasus, where it is found in foothill steppes, pine stands near lakes, montane decidous forests and gardens of the semi-desert area (Aliev 1984). In Talysh it is found in montane steppe meadows from 1600-2000 m a. s. 1. Nesting above the ground. 
Food plants: Pyrus communis, P. salicifolia, Malus domestica, Filipendula ulmaria, Astragalus cruciatus, Trifolium montanum, Cephalaria sp., Onosma sp., Anchusa sp., Veronica officinalis, Lamium album, Carduus onopordoides, Eryngium campestre.

\section{Bombus rebbinderi Vogt, 1909}

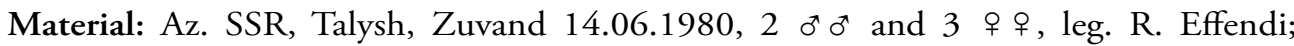
Same locality, mt. Nudis-galasi, Talysh, 12.06.1936, ㅇ, leg. Bogachev; Same locality

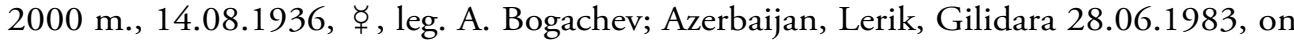

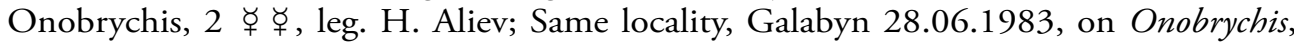
8 ఛ

Distribution: South Crimea, North Caucasus, Transcaucasia, northern Iran (Panfilov 1956).

Remarks: In Azerbaijan occurs in montane oak-ash forests, mountain meadows and gardens of foothill semi-desert belt of the Lesser Caucasus (Aliev 1980, Aliev 1984). In Talysh it is found in montane steppes and steppe meadows up to $2000 \mathrm{~m}$. Nest above the ground.

Food plants: Onobrychis cornuta, Pyrus sp., Malus domestica, Prunus domestica, P. divaricata, Crataegus sp., Rosa canina, Trifolium silvarum, T. repens, Valeriana officinalis, Cephalaria sp., Lamium album, Salvia sp., Scorzonera turcomanica, Carduus seminudus, Cirsium incanum, Echinops sphaerocephalus, Onopordon acanthium.

\section{Bombus argillaceus (Scopoli, 1763)}

Material: Az. SSR, Lerik, Chokara 27.07.1976, 1 우 $10^{\star}, 1$ ㅜ , leg. H. Aliev; Azerb. SSR, Talysh, Zuvand, Gosmolyan 23.05.1979, ㅇ, leg. P. Kazarjan; Az. SSR, Lerik, Gilidara

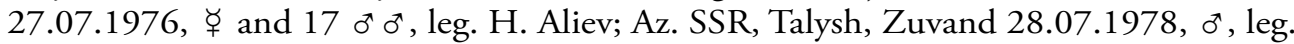
R. Effendi; Azerbaijan, Lerik, Galabyn 6.05.1983, $\Varangle$, leg. H. Aliev.

Distribution: Mediterranean steppe species. South-western Palaearctic: in South and partly Central Europe, Asia Minor, North Iran, Transcaucasia, and mountains of Turkmenia (Skorikov 1938, Reinig 1974).

Remarks: In Azerbaijan it is found in foothill steppes, low mountain oak-ash forests and montane steppes (Aliev 1984). In Talysh occurs in montane steppe meadows up to $2000 \mathrm{~m}$. Nest on the ground.

Food plants: Prunella sp., Lamium album, Urtica sp., Filipendula vulgaris, Melilotus albus, Lotus caucasicus, Coronilla varia, Onobrychis cornuta, Anchus italica, Veronica officinalis, Betonica orientalis, Carduus sp., Echinops sphaerocephalus.

\section{Bombus hortorum (Linnaeus, 1761)}

Material: Talysh, Mt. Nydis-galasi 12.06.1936, 우 leg. Bogachev.

Distribution: Palaearctic species. Widely distributed in the north part of Eurasia from western Europe to the Far east, from forest-tundra zone to Transcaucasia, the mountains of Central Asia and northern Mongolia (Panfilov 1957). 
Remarks: In Azerbaijan it is found in foothill steppes and gardens, low mountain open oak-ash forests, montane deforested areas, covered by meadow vegetation, and mountain steppes in The Lesser Caucasus (Aliev 1984). In Talysh occurs in mountain steppes up to $2000 \mathrm{~m}$. Nest underground.

Food plants: Astragalus sp.

\section{Bombus alboluteus Pallas, 1771}

Material: Talysh, Mt. Kizilisa 16.08.1936, o, leg. Bogachev.

Distribution: Caucasian sub-endemic. Transcaucasia, north-eastern Turkey and northern Iran.

Remarks: In Azerbaijan occurs near lakes in montane mixed forests, and also in subalpine and alpine meadows (Aliev 1984). Nest unknown.

Food plants: Carduus thoermeri.

\section{Bombus armeniacus Radoszkowski, 1877}

Material: Az. SSR Lerik, Gilidara 18.05.1976, ㅇ , leg. H. Aliev;Same locality 27.07.1976, $7 \not{\varphi} \succ$ and $2 \sigma^{\star} \sigma^{\star}$, leg. H. Aliev;Az. SSR Talysh, Zuvand 10.07.1979, 3 ㅇ ㅇ , leg. R. Effendi; Same locality 28.07.1978, ఛ , leg. R. Effendi;Az. SSR Lerik, Galabyn 23.07.1976, 2 ఛ leg. H. Aliev; Same locality 6.07.1983, 4 ఛ $\Varangle$, leg. H. Aliev;Az. SSR, Lerik, Gosmolyan 23.07.1978, ఛ, leg. H. Aliev; Azerbaijan, Lerik, Gilidara 1700 m. 26.05.1983, 6 우 우, leg. H. Aliev.

Distribution: Distributed in steppes of Eurasia, from Transcaucasia through south European part of the former USSR and Kazakhstan to the mountains of Central Asia (Panfilov et al. 1961, Reinig 1974).

Remarks: In Azerbaijan it occurs in montane steppes where Eryngium nigromontanum dominates (Aliev 1984) in the Lesser Caucasus. In Talysh it is found in montane steppes from 1600-1900 m a. s. l. Nest underground.

Food plants: Eryngium nigromontanum, Satureja laxiflora, Mentha longifolia, Echinops sphaerocephalus, Cousinia sp., Carduus thoermeri, Onopordon sp., Sonchus oleraceus, Allium sp.

\section{Bombus melanurus Lepeletier, 1836}

Material: Azerbaijan Lerik, Mt. Kemirkey 2400 m. 10.07.1983, ㅇ, leg. H. Aliev.

Distribution: Southern part of Caucasian isthmus, northeastern Turkey, northern Iran, Syria, Lebanon, mountains of Central Asia, Afghanistan, Altai, Mongolia, China (East Tien-Shan, curve of Khuankhe River), Pakistan, Nepal, Sikkim, Tibet (Williams 1991).

Remarks: In Azerbaijan it is found in the Lesser Caucasus, in highmountain and subalpine meadows with prevalence of Eryngium and Thymus (Aliev 1984). In Talysh occurs in mountain steppe meadows up to $2400 \mathrm{~m}$. Nest unknown.

Food plants: Eryngium nigromontanum. 


\section{Bombus fragrans (Pallas, 1771)}

Material: Azerbaijan, Lerik, mt. Kemirkei 2400 m. 12.07.1983, ㅇ, leg. H. Aliev.

Distribution: Widespread in the south-west Palaearctic: south-east Europe, Transcaucasia, Asia Minor, Kazakhstan, mountains of Central Asia (Kirgizia), the South of West Siberia, western part of China and northern Mongolia (Skorikov 1923, Skorikov 1938).

Remarks: Steppe species. In Azerbaijan occurs in mountain steppes of the Lesser Caucasus up to $3000 \mathrm{~m}$. In Talysh it is found up to the height of $2400 \mathrm{~m}$. in mountain steppes.

Food plants: Scrophularia sp., Trifolium ambiguum.

\section{Bombus subterraneus latreillellus (Kirby, 1802)}

Material: Azerb. SSR Lerik, Gosmolyan 23.07.1978, ఛ̧, leg. H. Aliev.

Distribution: Widely distributed Palaearctic species.

Remarks: Inhabits meadows of forested area, and meadow steppes (Panfilov et al., 1961). In Azerbaijan occurs in foothill steppes in the Lesser Caucasus (Aliev 1984). In Talysh it is found in mountain steppes up to $1600 \mathrm{~m}$. Nesting above the ground.

Food plants: Teucrium sp.

\section{Bombus lucorum (Linnaeus, 1761)}

Material: Az. SSR Lerik, Galabyn 23.07.1976, ఫ leg. H. Aliev; Lenkoran, Alekseevka 27.04.1936, ఫ̛, leg. Bogachev.

Distribution: Very widespread in Palaearctic: from West Europe to the Far East, from forest-tundra to Iran, mountains of Central Asia and Tibet (Panfilov et al. 1961, Aliev 1984).

Remarks: Occurs in open forests, lowland and mountain meadows, partly in steppes (Panfilov et al. 1961), foothill gardens, low mountain forests, montane decidous forests, subalpine meadows and azonal vegetation in low mountain landscape (Aliev 1984). In Talysh it is found in gardens in lowlands and mountain steppes. Nest underground.

Food plants: Trifolium repens, Cirsium falconeri, Pyrus communis, Malus domestica, Prunus domestica, P. spinosa, P. divaricata, Armeniaca vulgaris, Cerasus avium, Astragalus sp., Salvia sp.

\section{Bombus apollineus Skorikov, 1910}

Material: Azerbaijan, Lerik, Mt. Kemirkey 20.06.1983, 우, leg. H. Aliev.

Distribution: Caucasian sub-endemic. Occurs in the west of the Greater Caucasus, in Transcaucasia and in north-eastern Iran (Skorikov 1938, Baker 1996).

Remarks: In Azerbaijan it is found in the Lesser Caucasus, in low mountain forests, xerophyte formations and steppe meadows (Aliev 1984). In Talysh in mountain steppes up to $2400 \mathrm{~m}$. Nest unknown.

Food plants: Salvia viridis. 


\section{Bombus vorticosus Gerstaecker, 1872}

Material: Azerb. SSR, Lerik, Gilidara 26.07.1976, 3 ๙ $\sigma^{\star}$, leg. H. Aliev; Az. SSR, Lerik, Gosmolyan 24.07.1976, ఛ̧, leg. H. Aliev; Same locality 24.05.1979, ఛ̧, leg. P. Kazaryan; Same locality 23.07.1978, 3 $\Varangle \quad$, leg. H. Aliev; Talysh, Zuvand 20.05.1980, ㅇ, leg. R. Effendi.

Distribution: Balkan Peninsula, Asia Minor, Iran, Caucasus and Turkmenia (Kopetdag) (Skorikov 1938, Reinig 1974).

Remarks: Habitats are mountain steppes and meadows. In Azerbaijan it is found in montane steppe meadows, montane steppes and subalpine meadows of the Lesser Caucasus (Aliev 1984). In Talysh occurs in montane steppes. Nest above the ground.

Food plants: Padus racemosa, Trifolium sp., Eryngium campestre, E. nigromontanum, Senecio orientalis.

\section{Bombus eriophorus caucasicus Radoszkowski, 1860}

Material: near Lenkoran, glade 10.06.1929, ఛ , leg. E. Selivanchik.

Distribution: Caucasian endemic, including boh northern Caucasus and Transcaucasia (Skorikov 1938).

Remarks: In Azerbaijan occurs in low mountain steppe meadows, foothill steppes, middle montane open forests and meadows (Aliev 1984). In Talysh it is found in lowland forests in the glades. Nest unknown.

Food plants: Trifolium sp., Ranunculus sp.

\section{Bombus incertus Morawitz, 1881}

Material: Azerbaijan, Lerik, Mt. Kemirkey 20.06.1985, ఛ̛ , leg. H. Aliev.

Distribution: Caucasian sub-endemic. Occurs in the Greater Caucasus, Transcaucasia, north-eastern Turkey and northern Iran (Skorikov 1938, Nikolskaya and Popov 1958, Reinig 1974, Özbek 1976, Baker 1996).

Remarks: In Azerbaijan occurs in alpine and subalpine meadows in the Lesser Caucasus (Aliev 1984). In Talysh it is found in montane steppe meadows up to $2300 \mathrm{~m}$. Nest underground.

Food plants: Astragalus sp.

\section{Bombus haematurus Kriechbaumer, 1870}

Material: Az. SSR, Lerik, Kalakhan 24.07.1976, ఛ̧, leg. H. Aliev.

Distribution: South Europe, Asia Minor, Central Asia (Kopetdag), Caucasus (Skorikov 1938, Reinig 1974, Baker 1996).

Remarks: In Azerbaijan occurs in foothill gardens and steppes, low montane steppe meadows and open forests, in glades of deciduous middle montane forests (Aliev 1984). In Talysh it is found in montane steppe meadows at $1600 \mathrm{~m}$ a. s. 1 . Nest above the ground. Food plants: Astragalus sp. 


\section{Bombus pratorum (Linnaeus, 1761)}

Material: Azerbaijan, Lerik 16.08.1984, ఛ̧ ఛ, leg. H. Aliev.

Distribution: Europe, Asia Minor, Central Asia, Caucasus (Skorikov 1938, Reinig 1967).

Remarks: In Talysh occurs near the upper border of forest at $900 \mathrm{~m}$ a. s. 1. Nest unknown.

Food plants: Satureja sp.

\section{Conclusions}

In lowlands and on foothills up to $1000 \mathrm{~m}$, where the climate is humid subtropical, bumble bees are represented only by four taxa: Bombus lucorum, B. zonatus apicalis, $B$. daghestanicus, B. eriophorus caucasicus. This is apparently due to the strong anthropogenic influence in that area, which results in a decrease of both species diversity and population density. The most important plants visited by bumble bees in these areas, growing mostly in glades and at the edges of forest, are several species of dutch clover (Trifolium), Rubus fruticosus, Albizia julibrissin, Ranunculus, Vicia, Zelkova, Gleditschia caspica, Diospyros kaki, Malus and Pyrus.

In the area of dry steppes and steppe meadows with continental climate (with small areas of subalpine vegetation) from 1200 to $2400 \mathrm{~m}$ a. s. $1 ., 18$ bumble bee species are represented. The majority is endemic to the steppes and higher mountains: Bombus argillaceus, B. simulatilis, B. armeniacus, B. alboluteus, B. vorticosus, B. mlokosiewit$z i i, B$. incertus, $B$. persicus, $B$. melanurus. Here bumble bees are trophically related to Astragalus, Acantholimon, Thymus, Eryngium, Cirsium, Salvia and Symphytum. In riverbeds and ravines, where vegetation is more mesophile, bumble bees forage on Chicorium, Mentha, and in the spring on orchard trees. In this area bumble bees nest primarily in the ground, under stones, where they use old burrows of rodents and also other appropriate hollows.

\section{Acknowledgements}

The author received a grant (A/05/38414) from the German Academic Exchange Service (DAAD). Dr. E. Hüseynov (Baku) and A. D. Liston (Müncheberg) assisted with language improvements to the manuskript.

\section{References}

Aliev H. A. 1978: To the fauna of bumble bees (Hymenoptera, Apidae) of Lenkoran area, Azerbaijan. Materials of the $2^{\text {nd }}$ Scientific Session of Entomologists of Azerbaijan, Elm, Baku, 18.

Aliev H. A. 1980: To the knowledge of the bee fauna (Hymenoptera, Apoidea) of the East regions of Caucausus Minor in Azerbaijan. - Materials of the Scientific Conference of Graduate Students of the Academy of Sciences of Azerbaijan, Baku 2: 32-35.

Aliev H. A. 1984: To the fauna and zoogeography of bumble bees of Caucasus Minor within the territory of Azerbaijan. - Bulletin of Moscow Society of Naturalists, biological branch, Moscow 89 (6): 35-40.

BAKER D. B. 1996: On a collection of humble-bees from northern Iran (Hymenoptera: Apoidea, Bombinae).

- Beiträge zur Entomologie, Berlin 46: 109-132. 
Nikolskaya, M. N. \& Popov V. V. 1958: Hymenoptera [of the Caucasus]: 318-351. - In: Vinogradov, B. S. (ed.), Animals of the USSR. Vol. 5. Highland Regions of the European Part of the USSR. - 655 pp.; Academy of Sciences of the USSR, Moscow \& Leningrad.

Özвек, H. 1976: Pollinator bees on alfalfa in the Erzurum region of Turkey. - Journal of Apicultural Research 15 (3/4): 145-148.

Osytshnjuk, A. Z.; Panfilov, D. V. \& Ponomareva, A. A. 1978: Superfamily Apoidea - Bees; pp. 279-519. - In: Medvedev, G. S. (ed.). A Key to Insects of the European Part of the USSR. Vol. 3. Hymenoptera. Pt. 1. [Aculeata]. - 583 pp. ; Nauka, Leningrad. - In: Keys to Animals in the Fauna of the USSR. Published by the Zoological Institute of the Academy of Sciences of the USSR, no. 119.

Panfilov, D. V. 1956: Contributions to the taxonomy of bumble bees (Hymenoptera, Bombinae) with description of new forms. - Zoologicheski Zhurnal, Moscow, 35 (9): 1325-1334.

Panfilov, D. V. 1957: On the geographical distribution of bumble bees (Bombus) in China. - Acta geographica sinica, Beijing 23: 221-239.

Panfilov, D. V.; Rossolimo, O. L. \& Syroyechrovskiy, E. E. 1961: On the fauna and zoogeography of bumble bees (Bombidae) of Tuva area. - Izvestiya Sibir. Otd. Akad. Nauk SSSR, Biol., Novosibirsk 6: 106-113.

ReInig, W. F. 1967: Zur Kenntnis der Hummelfauna einiger Gebirge West-Kleinasiens. - Nachrichtenblatt der Bayrischen Entomologen, Munich 9/10: 81-91.

ReInIG, W. F. 1971: Zur Faunistik und Zoogeographie des Vorderen Orients. Beitrag zur Kenntnis der Hummeln und Schmarotzerhummeln Anatoliens (Hym., Apidae). - Veröffentlichungen der Zoologischen Staatssammlung München, Munich 15: 139-165.

ReINIG, W. F. 1974: Faunistische und zoogeographische Studien in Kleinasien. 5. Auf Hummelfang im Taurus. - Nachrichtenblatt der Bayrischen Entomologen, Munich 4: 67-80.

SкоRiкоv, A. S. 1923: The bumble bees of the Palaearctic Region. Part 1. General biology (with inclusion of zoogeography). - Izvestiya Severnoi Stantsii Zaschity Rastenii, Petrograd 4: 1-160.

SкоRıкоv, A. S. 1931: Die Hummelfauna Turkestans und ihre Beziehungen zur zentralasiatischen Fauna (Hymenoptera, Bombidae). Pp. 175-247. - In: Lindholm, V. A. (ed.), Pamir-Expedition 1928. Abhandlungen der Expedition. Lieferung VIII. Zoologie. - 247 pp. Academy of Sciences of the USSR, Leningrad.

SкоRIкоv, A. S. 1938: Zoogeographic patterns in the bumble bee faunas of the Caucasus, Iran and Anatolia (Hymenoptera, Bombinae). - Entomologicheskoye obozrenie, Leningrad 27 (3/4): 145-151.

SkHirtladze, I. A. 1979: Contribution to the fauna of bees (Hymenoptera, Apoidea) in arid areas of Transcaucasus; pp. 115-145. - In: Gegechrozi, A. M. [A Collection of Scientific Papers]. - 166 pp. Mezniereba, Tbilisi.

Williams, P. H. 1991: The bumble bees of the Kashmir Himalaya (Hymenoptera: Apidae, Bombini). - Bulletin of the British Museum (Natural History), Entomology Series, London 60: 1-204.

\section{Author's address:}

Dr. Halid A. Aliev

Institute of Zoology, Azerbaijan National Academy of Sciences

Baku, 370073, proezd 1128, kvartal 504,

Azerbaijan

e-mail: khalidaliyev@yahoo.com 